scree. The geophysical survey (Thorning \& Boserup, this report) indicates that these sulphide-enriched fault zones extend into the basement rocks. Scattered pyrite-rich blocks were found in the area of the basement rocks. Furthermore, the basement granite adjacent to the mineralised faults is altered and contains sporadic pyrite and galena.

The northernmost E-W trending steep fault in south-east Motzfeldt Centre, on a steep cliff face south of Sermia qiterdleq, contains a sulphide mineralisation which is readily seen from a distance due to its conspicuous ochreous weathering. This sulphide mineralisation could not be visited. During a helicopter reconnaissance in 1982 molybdenite-bearing blocks were found below this fault.

Pyrite is the most common sulphide found so far in the mineralised fault zones. The identification of other sulphides on the outcrops of the intensively weathered, metasomatically altered syenites is difficult, and consequently their abundance and economic significance are still to be investigated.

Acknowledgements. The field work was supported by the European Economic Community through contract number MSM-118-DK(AD). The author wishes to thank J. Lau for his invaluable work as base camp manager in Narssarssuaq and the members of the individual field groups for their contributions to the field work and enjoyable co-operation in the field.

\title{
References
}

Armour-Brown, A., Tukiainen, T. \& Wallin, B. 1981: Uranium districts in South Greenland. Rapp.Grønlands geol. Unders. 105, 51-55.

Armour-Brown, A., Tukiainen, T., Nyegaard, P., Wallin, B. 1984: The South Greenland regional uranium exploration programme. Final report of progress 1980-1983. Unpubl. intern. GGU rep., 107 pp.

Tukiainen, T., Bradshaw, C. \& Emeleus, C. H. 1984: Geological and radiometric mapping of the Motzfeldt Centre of the Igaliko Complex, South Greenland. Rapp. Grønlands geol. Unders. 120, 78-83.

\section{Geological investigations of the Igaliko dyke swarm, South Greenland}

\author{
N. J. G. Pearce and C. Henry Emeleus
}

Field work in 1984 in the Motzfeldt area included an investigation of the Gardar dyke swarm in this area. The dyke swarm was examined at the following places in or near the Igaliko Complex: north of Motzfeldt S $\varnothing$, north of Gieseckes Dal, Igaliko, Flinks Dal, Mellemlandet, in Østfjordsdal (north-west side), and west of Narssarssuaq river.

Except at $\emptyset$ stfjordsdal, the dykes resemble assemblages found elsewhere in the TugtutôqIlímaussaq-Igaliko swarm. Porphyritic and non-porphyritic trachytes and phonolites (the latter less common), basalts and dolerites, lamprophyres, big feldspar dolerites and carbo- 
natites are all present. The latter are much more abundant than previously recognised, and are occasionally of considerable length. The relative proportions vary; basaltic and doleritic dykes are particularly abundant towards the centre of the swarm, i.e. west of Narssarssuaq river where dilation due to dykes is greatest, at about 10 per cent; elsewhere values of 3-4 per cent were obtained.

Examination of the dykes in lower Flinks Dal shows that the swarm undergoes a left lateral displacement across the major Flinks Dal fault. Movement is considerable (over $2 \mathrm{~km}$ ) but may be less than the $6 \mathrm{~km}$ estimated for syenite displacements (Tukiainen et al., 1984).

The extensive dyke swarm present between syenites of the late Igdlerfigssalik Centre (Emeleus \& Harry, 1970) and the Østfjordsdal gravel flats differs markedly from the main Gardar swarm to the north-west: the dykes are typically very fresh microsyenites accompanied by a few lamprophyres. Close to the Igdlerfigssalik syenites there is a prominent group of porphyritic syenite dykes up to $15 \mathrm{~m}$ in width, characterised by large phenocrysts of alkali feldspar and nepheline. These dykes are cut by the $\emptyset$ stfjordsdal satellite syenite (Emeleus \& Harry; 1970) and extend far to the south-west. They are equated with the Fox Bay porphyry dykes (Ussing, 1912).

A large collection was made from the dykes for petrological and geochemical studies.

Acknowledgements. N. J. G. P. thanks NERC, United Kingdom, for financial support. C. H. E. gratefully acknowledges financial assistance from the Royal Society and Durham University. Both thank GGU for invaluable support in the field.

\section{References}

Emeleus, C. H. \& Harry, W. T. 1970: The Igaliko nepheline syenite complex. General description. Bull. Grønlands geol. Unders. 85 (also Meddr Grønland 186,3) 116 pp.

Tukiainen, T., Bradshaw, C. \& Emeleus, C. H. 1984: Geological and radiometric mapping of the Motzfeldt Centre of the Igaliko Complex, South Greenland. Rapp. Grønlands geol. Unders. 120, 78-83.

Ussing, N. V. 1912: Geology of the country around Julianehaab, Greenland. Meddr Grønland 38, 376 pp.

Department of Geological Sciences, University of Durham, Science Laboratories, South Road, Durham, U. $K$. 